\title{
Assessment of Browse Availability and Suitability for Black Rhino's Re-Introduction in Northern Gonarezhou National Park, Southeastern Zimbabwe
}

\author{
David Goza ${ }^{1}$, Patience Zisadza-Gandiwa ${ }^{2 *}$, Clayton Mashapa ${ }^{3 \#}\left(\mathbb{D}\right.$, Never Muboko $^{3}$, \\ Edson Gandiwa ${ }^{3 *}$
}

${ }^{1}$ Mushandike College of Wildlife Management, Zimbabwe Parks and Wildlife Management Authority, Masvingo, Zimbabwe ${ }^{2}$ Transfrontier Conservation Areas Unit, Zimbabwe Parks and Wildlife Management Authority, Causeway, Harare, Zimbabwe ${ }^{3}$ School of Wildlife, Ecology and Conservation, Chinhoyi University of Technology, Chinhoyi, Zimbabwe

Email: "clayiemashapa@yahoo.co.uk

How to cite this paper: Goza, D., Zisadza-Gandiwa, P., Mashapa, C., Muboko, N. and Gandiwa, E. (2019) Assessment of Browse Availability and Suitability for Black Rhino's Re-Introduction in Northern Gonarezhou National Park, Southeastern Zimbabwe. Open Journal of Ecology, 9, 326-335. https://doi.org/10.4236/oje.2019.99023

Received: August 3, 2019

Accepted: September 6, 2019

Published: September 9, 2019

Copyright $\odot 2019$ by author(s) and Scientific Research Publishing Inc. This work is licensed under the Creative Commons Attribution International License (CC BY 4.0).

http://creativecommons.org/licenses/by/4.0/

CC) (7) Open Access

\begin{abstract}
Wildlife reintroduction regulations require feasibility assessment to inform planning. The study aims to contribute to the existing knowledge on northern Gonarezhou National Park (GNP), southeastern Zimbabwe, prior to the black rhino re-introduction project. The study objective was to assess browse availability and suitability for black rhino re-introduction in northern GNP. We stratified the study area into two strata, i.e. north and south of Runde River in GNP. A total of 96 sample plots measuring $20 \mathrm{~m} \times 30 \mathrm{~m}$ (i.e., 48 plots in each study stratum) were randomly placed across the study strata, between March and April 2011. Woody plant variables recorded are: shrub height, shrub canopy diameters, evidence of browsing on woody plants, number of shrubs and woody species. Principal browse frequency of occurrence and proportional quality of woody species were categorized and analyzed in combination with knowledge on the woody species' value to black rhino diet. Preferred woody species were determined using browse suitability/electivity index. A total of 3201 woody plants were recorded across the study strata. Woody species diversity and black rhino's browse suitability/electivity value significantly $(p=0.001)$ differed across the study strata. However, there were no significant differences in shrub density, shrub canopy volume and density of browsed plants. Common principal forages were recorded and included: knob thorn Acacia (Acacia nigrescens), small-leaved sickle-bush (Dichrostachys cineria) and tamboti (Spirostachys africana). The study suggested that black
\end{abstract}

${ }^{\star}$ Formerly, Scientific Services, GonarezhouNational Park, Parks and Wildlife Management Authority, Private Bag 7003, Chiredzi, Zimbabwe. 
rhino's browse suitability, preferred browse woody species, woody species diversity and proportional browse availability, as selected attributes are favorably more pronounced in the northern side of the Runde River in GNP, suggesting it is more suitable as a sanctuary for the black rhino re-introduction programme. It was recommended that black rhinos could be re-introduced in the northern GNP area provided other important factors such as law enforcement are taken into consideration.

\section{Keywords}

Black Rhino, Browse Availability, Gonarezhou, Habitat Suitability, Woody Species

\section{Introduction}

In the Middle Eocene period, the true Rhino family (Rhinocerotidae) was a very abundant and diverse group of mammals and widely distributed throughout Africa, Asia, Europe and North America, with 41 genera and 142 species [1] [2] [3]. By the end of Pleistocene, most rhino species became extinct in most areas they used to exist mainly due to hunting and over-exploitation, hence, today the family is now confined to the sub-Saharan Africa and south-east Asia. black rhino (Diceros bicornis) is a critically endangered mega-herbivore of sub-Sahara Africa [4]. As recognized [5], the species experiences reduced population due to illegal hunting caused by the illicit trade in rhino horn. In Zimbabwe, the black rhino species is specially protected, and the rhino population is below the minimum viable population level required to provide long term genetic security [6], however, illegal hunting remains a problem [7] [8].

Following local extirpation of black rhinos in Gonarezhou National Park (GNP), southeastern Zimbabwe around the 1940s, the first two rhinos appear to have been released during 1969 [9]. The second introduction of 77 black rhinos was conducted in the present GNP, Zimbabwe during the 1970s, and this was after the first local extirpation in the park. Unfortunately, poaching of wildlife in GNP increased, e.g. the number of black rhinoceros killed peaked to 51 in 1984 and by 1994 the black rhinos were locally extinct in GNP for the second time [6] [9]. Meanwhile, at the peak of rhino poaching in Zimbabwe in the late 1980s, the Zimbabwe Parks and Wildlife Management Authority (ZPWMA), a state agency with the overall responsibility for wildlife protection, decided to relocate all black rhinos from vulnerable areas across the country and confine them to four state owned Intensive Protection Zones (IPZs) in Zimbabwe (i.e., Sinamatella, Matopos, Matusadona National Park and Chipinge Safari Area/Intensive Protection Zone) and private conservancies for enhanced protection [8].

However, to improve the diversity of wildlife in the GNP and enhance its attractiveness as a tourist destination, the ZPWMA proposes to establish an IPZ in northern GNP with the black rhino species being re-introduced by the 2020s and beyond [6]. The IPZ proposal is evaluated in this research article with specific 
reference to habitat variables, i.e., browse availability and suitability for black rhinos, within northern GNP. Wildlife translocation, introduction or reintroduction regulations require feasibility or an ecological assessment to inform the reintroduction planning [10]. Hence, the present study is aimed at contributing to the existing body of knowledge on northern GNP and similar habitat status prior to the black rhino re-introduction project following the last assessment conducted in 2005 [9]. Specifically, the study objective was to assess the browse availability and suitability for black rhino re-introduction in northern GNP, based on selected woody vegetation attributes.

\section{Materials and Methods}

\subsection{Study Area}

GNP is situated in the southeastern region of Zimbabwe between latitude $21^{\circ} 15^{\prime} \mathrm{S}$ and longitude $30^{\circ} 32^{\prime} \mathrm{E}$ and covering $5053 \mathrm{~km}^{2}$ (Figure 1). GNP constitutes part of the Greater Limpopo Transfontier Conservation Area, together with other protected areas like the Kruger National Park in South Africa and the Limpopo National Park in Mozambique. GNP and its surrounding areas experience short dry winter season in June and July with temperatures below $30^{\circ} \mathrm{C}$ and a hot wet summer season from November to April when temperatures can exceed $40^{\circ} \mathrm{C}$. The remaining months are hot and dry [6]. The mean annual rainfall is $466 \mathrm{~mm}$ but is highly variable [11] [12]. Two severe droughts have occurred since 1961 and the 1991/1992 drought led to the death of large numbers of wildlife [6]. The climate of northern GNP and its surrounding Safari areas is semi-arid [11], and vegetation that is predominantly dry deciduous savanna woodland of varying types dominated by Colophospermum mopane woodland

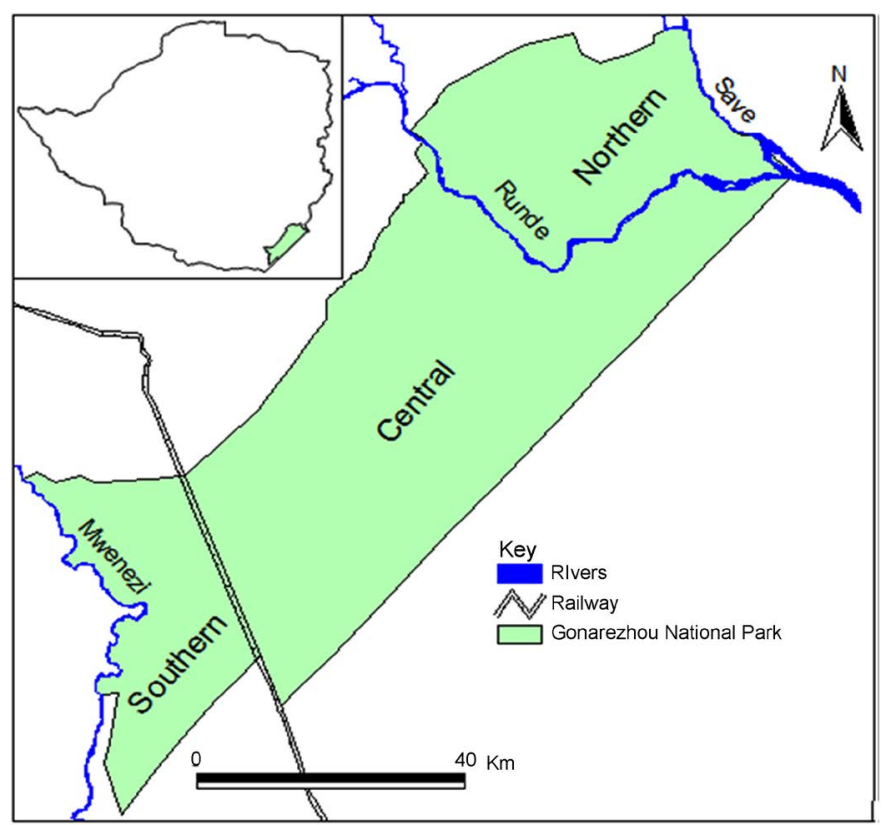

Figure 1. Location of the two study strata of north and south of Runde River in Gonarezhou National Park, southern Zimbabwe (Source, [15]). 
and riverine and alluvial woodlands [13] [14]. In 2016, the estimated population numbers of the principal large herbivores in GNP were: African elephant (Loxodonta africana) 10,715 (upper and lower $95 \%$ confidence limits $\pm 17.5 \%$ ); impala (Aepyceros melampus) 7421 ( $\pm 27.3 \%)$; African buffalo (Syncerus caffer) 4797 ( $\pm 50.7 \%), \mathrm{kudu}$ (Tragelaphus strepsiceros) 1789 ( $\pm 27.6 \%)$; zebra (Equus quagga) 1830 ( $\pm 26.2 \%$ ); wildebeest (Connochaetes taurinus) 929 ( $\pm 43.4 \%$ ); giraffe (Giraffa camelopardalis) $446( \pm 36.8 \%)$; eland (Taurotragus oryx) $241( \pm 81.6 \%)$; nyala (Tragelaphus angasii) $187( \pm 47.1 \%)$ and waterbuck (Kobus ellipsiprymnus) 326 ( $\pm 60.3 \%)[7]$.

The study area which is the Save-Runde River sub-region in northern GNP has a total spatial extent of approximately $3000 \mathrm{~km}^{2}$ [6].

\subsection{Data Collection}

We stratified the study area into two strata, both sides of the perennial Runde River in GNP. The basis for stratifying on the left and right side of the river was premised on the fact that the perennial river with its high levels of water flow would tend to be a physical barrier to the rhinos preventing them to easily access all the sides of the banks of Runde River [14] [15]. The data reported in this study were also used in a previous study where soil type was assessed on how it influences the structure and composition of woody species within the same study area of northern GNP [14]. A total of 96 sample plots measuring $20 \mathrm{~m} \times$ $30 \mathrm{~m}$ (i.e., 48 plots in each study stratum) were randomly pegged based on GNP topographical map using grid intercept method, within the defined study area, between March and April 2011. Woody plant species observed within a sample plot were identified using the field guide [16] and recorded. The Linnean system of binomial nomenclature was used to classify woody plant species. Woody species taxa procedure method by comparison of an unknown woody species with named specimens, photographs, illustrations or descriptions were done using the keys in a southern Africa flora manual, guide handbook by [16]. In this present study, trees were defined as rooted, woody, self-supporting plants $\geq 3 \mathrm{~m}$ high with one or a few definite trunks ( $\geq 6 \mathrm{~cm}$ in basal stem diameter) whereas shrubs were defined as rooted, woody, self-supporting, multi-stemmed or single stemmed plants $<3 \mathrm{~m}$ high and $<6 \mathrm{~cm}$ in stem basal diameter [12]. Specifically, the following woody plant variables were recorded: shrub height, shrub canopy diameters, evidence of browsing on woody plants, number of shrubs, and woody species name following the methods outlined by [12]. A visual method of recording canopy cover and shrub height was followed by an assessment of the woody species contributing to the available browse for black rhino as outlined by [17]. When plant resources are used disproportionately to their availability, use is said to be selective. The availability of plant resources was considered as quantity which can be accessibly to a population of black rhinos during the study time.

\subsection{Data Analysis}

The Shannon-Weiner diversity index $(H)$ was used to calculate the woody spe- 
cies diversity for each of the study stratum [18]. Data were tested for normality using Shapiro-Wilk test in STATISTICA for Windows version 6 software [19]. As a requirement to satisfy the assumptions of normality and equality of variance, data were normalized using: $\log 10(y+1)$ where $y$ is the recorded plant variable. Measured variables were tested for differences between the study strata using the two tailed Student $t$-test. Black rhino's principal browse frequency of occurrence and proportional quality of woody species was categorized and analyzed following a standard procedure by [20]. Browse quality ranking was conducted in combination with the knowledge on the woody species' value to potential black rhino diet following [21] known forage data as reference. This was in accordance to the study by [21], which used the backtracking method to track black rhinos and record their diet composition assessing woody species browsed by black rhinos. With reference to available forage data on the diet of black rhinos, we determined principal wood species that constitute the diet of black rhino as recorded across the study area.

In order to determine which woody species are preferred by black rhinos we followed the method of [21], where the proportional value of each woody species in the black rhino's diet was divided by the abundance of that woody species available in a sample plot. A unit value which serves as an indicator for the black rhino's level of preference of particular woody species was calculated following the formula of [22] as cited in [21]: $E_{i}=\left(r_{i}-n_{i}\right) /\left(r_{i}+n_{i}\right)$ where $E$ is the browse suitability/electivity measure for woody species $i, r$ is the percentage of woody species $i$ in the diet, and $n$ is the percentage of woody species $i$ in the environment (sample plot). This equation yields values ranging from -1 to 1 . A value close to -1 indicates an avoidance of a woody species, a value of 0 shows no preference, and a value close to 1 illustrates a high preference for a woody species. Values of neither -1 nor 1 can be reached. Calculation of the browse suitability/electivity index was based on a list of woody plant attributes, important for the black rhinos, combined in a simple equation of $E_{i}$. Range of variation of each parameter was divided into classes to which scores of browse suitability/electivity index ranging from -1 to 1 which were attributed to the standard measures by [21]. In order to estimate the browse suitability/electivity index scores, we considered the successional stage of woody plants in the plots (height), share of principal taxa/forage woody species preferred by black rhinos, canopy volume of the shrub layer, percentage cover of shrubs. The browse suitability/electivity index was calculated after [21], from the equation $E_{i}$. Principal woody species were defined as those that comprised $\geq 5 \%$ of the total number of bites made by the black rhino as earlier reported elsewhere in Matusadonha National Park, northern Zimbabwe [20] and [21]. Preferred woody species were determined using the browse suitability/electivity index described above and in [22]. Following several studies [20] [21] [22], those taxa with browse suitability/electivity indexes greater than 0.4 and comprising at least $1 \%$ of total measured diet are reported and discussed in this present study. 


\section{Results}

A total of 3201 individual woody plants were recorded within the two study strata. Woody species diversity and black rhino's browse suitability/electivity value significantly differed $(p=0.001)$ across the study strata (Table 1$)$. However, there were no significant differences in shrub density $(p=0.398)$, shrub canopy volume ( $p=0.893)$ and browsed plant density $(p=0.219)$.

The number of woody species was more regular in the northern side of the Runde River study stratum in comparison to the southern side of the Runde River (Table 2). Woody species recorded in northern GNP as common principal forage which dominated the standard reference of black rhino diet, were: knob thorn Acacia (Acacia nigrescens), small-leaved sickle-bush (Dichrostachys cineria), wild rubber horn pod tree (Diplorhynchus condlycarpon), tamboti (Spirostachys africana), and white-berry bushweed (Flueggea virosa) (Table 2), with different frequency of occurrence and proportion of availability.

With reference to standard forage data of black rhino diet, Acacia spp. comprised $5.34 \%$ of the total diet and had a browse suitability/electivity index of 0.70. Euclea spp. comprised $20.53 \%$ of the total diet and had a browse suitability/electivity index of 0.99 , while the remainder of the Combretum spp. taxa comprised an additional $6.96 \%$ of total diet and possessed a browse suitability/electivity index of 0.92 . The Faidherbia spp. comprised $7.6 \%$ of the total

Table 1. Vegetation variables in both the northern and southern Runde River strata: results of a two-tailed Student $t$-test analysis.

\begin{tabular}{|c|c|c|c|c|}
\hline \multirow[t]{2}{*}{ Variables } & \multicolumn{2}{|c|}{$\begin{array}{c}\text { Mean } \pm \text { SE } \\
\text { Runde River Strata }\end{array}$} & \multirow[t]{2}{*}{$t$-value } & \multirow[t]{2}{*}{$p$ value } \\
\hline & Northern side & Southern side & & \\
\hline Browsed plant density ha ${ }^{-1}$ & $11.12 \pm 7.53$ & $1.32 \pm 0.82$ & 1.24 & 0.219 \\
\hline Shrub density ha ${ }^{-1}$ & $92 \pm 23.32$ & $53 \pm 18.52$ & 0.85 & 0.398 \\
\hline Shrub canopy volume $\left(\mathrm{m}^{3} / \mathrm{ha}\right)$ & $25,111 \pm 520$ & $26,272 \pm 720$ & -0.14 & 0.893 \\
\hline Woody species diversity $\left(H^{\circ}\right)$ & $1.35 \pm 0.09$ & $0.87 \pm 0.07$ & 2.23 & $0.001^{*}$ \\
\hline Browse suitability/electivity & $0.71 \pm 0.26$ & $0.88 \pm 0.96$ & -2.91 & $0.001^{\star}$ \\
\hline
\end{tabular}

Table 2. Mean frequency of occurrence and percentage proportional browse availability of five principal forage woody species.

\begin{tabular}{ccccc}
\hline \multirow{2}{*}{$\begin{array}{c}\text { Principal forage } \\
\text { woody species }\end{array}$} & \multicolumn{2}{c}{ South of Runde River stratum } & \multicolumn{2}{c}{ North of Runde River stratum } \\
\cline { 2 - 5 } & $\begin{array}{c}\text { Frequency of } \\
\text { occurrence }\end{array}$ & $\begin{array}{c}\text { Proportional } \\
\text { availability (\%) }\end{array}$ & $\begin{array}{c}\text { Frequency of } \\
\text { occurrence }\end{array}$ & $\begin{array}{c}\text { Proportional } \\
\text { availability (\%) }\end{array}$ \\
\hline Acacia nigrescens & 3 & 0,19 & 111 & 6.8 \\
Dichrostachys cineria & 14 & 0,9 & 85 & 5.21 \\
Diplorhynchus condlycarpon & 21 & 1,34 & 10 & 0.61 \\
Spirostachys africana & 26 & 1,66 & 31 & 1.9 \\
Flueggea virosa & 7 & 0,45 & 32 & 2 \\
\hline
\end{tabular}


diet and had a browse/electivity index that approached 1. The Grewia genus comprised $42.71 \%$ of total diet, contributing by far the largest amount to black rhinodiet and had a browse suitability/electivity index of -0.07 . These five principal taxa recorded in the present study comprised a total of $83.15 \%$ of the total diet of the black rhino (Table 3).

\section{Discussion}

The study results recorded no significant differences in shrub density, shrub canopy volume and browsed plant density across the study strata (Table 1). This suggested presence of highly browsed woody plants and dominance of shrubs in some sections of northern GNP as reported by earlier studies [23] [24] [25]. However, this can impact positively to black rhinos feeding habits and pattern which are known as selective for woody plant species and size [26]. The study highlighted a high shrub density across the study strata (Table 1). According to earlier studies [27] and [28], this is a key parameter of woody vegetation structure of importance to black rhino forage since mostly consumed shrubs are of a height below $2 \mathrm{~m}$. The importance of woody vegetation to black rhinos largely depends on the availability of preferred quality browse within the reach (plant height $\leq 2 \mathrm{~m}$ ) of the rhinos [26]. The synergy between the commonly reported fires and intense herbivory in GNP [12] [29] [30] will likely continue to contribute to the general modification of habitats, for example, reduced woody plant height and increased number of stems per plant, thereby, replacing woodlands with shrublands patches. This woody vegetation structural change likely to proliferate and persist across northern GNP, given the recorded no significant difference in shrub density and shrub canopy volume across the study strata could continue to set this section of the park as an ideal area for black rhino re-introduction.

Spirostachys, Dichrostachys and Acacia genera which are known palatable quality browse suitable for black rhino's feed [20] [21] were recorded with high frequency occurrence within the northern side of the Runde River study stratum, suggesting it to be a more suitable sanctuary space for the proposed re-introduction of black rhinos in northern GNP. Earlier studies in GNP confirmed abundance of Spirostachys woodlands [31] and Acacia woodlands [24] within northern GNP. The study results highlighted that north of Runde River

Table 3. Reference forage data: diet components of black rhinos (adapted from [21]).

\begin{tabular}{ccc}
\hline Principal taxa & \% of the diet of black rhino & Browse suitability/electivity index \\
\hline Grewia & 42.7 & -0.07 \\
Euclea & 20.5 & 0.99 \\
Faidherbia & 7.6 & 1 \\
Combretum & 6.9 & 0.93 \\
Acacia & 5.4 & 0.26 \\
Total & $\mathbf{8 3 . 2}$ & \\
\hline
\end{tabular}


had higher woody species diversity and black rhino's browse suitability/electivity values compared to the south of Runde River study stratum in northern GNP, southeastern Zimbabwe (Table 1, Table 2). Consistent with other studies, we recorded woody species of the following genera, the African bush willow (Combretum), mallow-leaved cross-berry (Grewia), bush guarri (Euclea), small-fruited potato bush (Phyllanthus), apple-ring acacia (Faidherbia), and chaste tree ( $\mathrm{Vi}$ tex), which are important food sources/forage for black rhinos in southern Africa [32] [33]. The woody plant genera that rank high in the diet of black rhinos in Zimbabwe are diverse, namely, Acacia, Aloe, Bauhinia, Combretum, Commiphora, Cordia, Croton, Diospyros, Diplorhynchus, Euphorbia, Grewia, Vitex and the fallen fruits of Kigelia africana [20] [34]. It was a positive finding that most of these woody species were recorded in northern GNP during the present study, over and above other recorded habitat forage status suggesting north of the Runde River as the most appropriate sanctuary of the proposed IPZ for black rhino re-introduction.

\section{Conclusion}

The study concluded that black rhino's browse suitability, preferred browse woody species, woody species diversity and proportional browse availability, as selected attributes are favorably more pronounced in the northern side of the Runde River in GNP, southeastern Zimbabwe, suggesting that it is potentially suitable as a sanctuary for the black rhino re-introduction programme. We recommend that the black rhinos could be re-introduced in the northern GNP area provided other important factors such as law enforcement and other IUCN reintroduction requirements are taken into consideration.

\section{Acknowledgements}

We thank the Zimbabwe Parks and Wildlife Management Authority and Frankfurt Zoological Society for supporting this study.

\section{Conflicts of Interest}

The authors declare no conflicts of interest regarding the publication of this paper.

\section{References}

[1] Goddard, J. (1968) Food Preferences of Black Rhinoceros Populations. East Africa Wildlife Journal, 6, 1-18. https://doi.org/10.1111/j.1365-2028.1968.tb00898.x

[2] Cerdeno, E. (1998) Diversity and Evolutionary Trends of the Family Rhinocerotidae (Perissodactyla). Palaeogeography, Palaeoclimatology, Palaeoecology, 141, 13-34. https://doi.org/10.1016/S0031-0182(98)00003-0

[3] Harley, E.H., Cunningham, J. and O’Ryan, C. (2005) Genetic Variation and Population Structure in Remnant Populations of Black Rhinoceros, Diceros bicornis in Africa. Molecular Ecology, 14, 2981-2990.

https://doi.org/10.1111/j.1365-294X.2005.02660.x 
[4] IUCN International Union of Conservation and Nature (2017) Red List of Threatened Species. Version 2017-3. http://www.iucnredlist.org

[5] Emslie, R. and Brooks, M. (1999) African Rhino. Status Survey and Conservation Action Plan. IUCN/SSC African Rhino Specialist Group. IUCN, Gland and Cambridge.

[6] ZPWMA Zimbabwe Parks and Wildlife Management Authority (2011) Gonarezhou National Park Management Plan: 2011-2021. Zimbabwe Parks and Wildlife Management Authority, Harare.

[7] Dunham, K.M and van der Westhuizen, H.F. (2016) Aerial Survey of Elephants and other Large Herbivores in Gonarezhou National Park (Zimbabwe) and Some Adjacent Areas: 2016. Frankfurt Zoological Society, Gonarezhou Conservation Project, Gonarezhou National Park, Chiredzi.

[8] Muboko, N. (2014) The Role of Man, Hand-Raised Black Rhinos and Elephants on Woody Vegetation, Matusadona National Park, Zimbabwe. Pachyderm, 56, 72-81.

[9] Du Toit, R., Mungwashu, L. and Dunham, K.M. (2005) The Reintroduction of Rhinos to Gonarezhou National Park, Zimbabwe: A Feasibility Study. SADC Regional Programme for Rhino Conservation, Harare.

[10] IUCN (1998) Guidelines for Re-Introductions. Prepared by the IUCN/SSC R-Introduction Specialist Group. IUCN, Gland, Cambridge, $10 \mathrm{p}$.

[11] Walker, B.H. (1976) An Approach to the Monitoring of Changes in the Composition and Utilisation of Woodland and Savanna Vegetation. South African Journal Wildlife Resources, 6, 1-32.

[12] Gandiwa, E. and Kativu, S. (2009) Influence of Fire Frequency on Colophospermum mopane and Combretum apiculatum Woodland Structure and Composition in Northern Gonarezhou National Park, Zimbabwe. Koedoe, 51, Article No. 685. https://doi.org/10.4102/koedoe.v51i1.685

[13] Clegg, B. (2003) Vegetation Map of Northern Gonarezhou National Park. Unpublished Map. Malilangwe Trust, Chiredzi.

[14] Gandiwa, E., Zisadza-Gandiwa, Goza, P.D., Mashapa, C. and Muboko, N. (2014) Diversityand Structure of Woody Vegetation across Areas with Different Soils in Gonarezhou National Park, Zimbabwe. Southern Forests. A Journal of Forest Sciences, 76, 111-116. https://doi.org/10.2989/20702620.2014.921007

[15] Zisadza-Gandiwa, P., Chiganze, S., Chirombe, P., Mashapa, C., Muboko, N. and Gandiwa, E. (2013) Abundance and Distribution of African Fish Eagles along Major Rivers in Gonarezhou National Park, Zimbabwe. Greener Journal Biological Science, 3, 36-341.

[16] Pelgrave, K.C. (1997) Trees of Southern Africa. Struik Publishers, Cape Town.

[17] Adcock, K. (2006) Visual Assessment of Black Rhino Browses Availability. Version 3 SADC Regional Programme for Rhino Conservation.

[18] Ludwig, A.J. and Reynolds, J.F. (1988) Statistical Ecology: A Primer on Methods and Computing. Journal Wiley \& Sons, New York.

[19] Statsoft Inc. (2001) STATISTICA for Windows, Version 6. StatSoft Inc. 2300, Tulsa.

[20] Matipano, G. (2003) A Comparison of Woody Browse Selection by Hand-Raised, Boma Adapted and Black Rhinoceros, (Diceros bicornis) in Matusadona National Park, Zimbabwe. Koedoe, 46, 83-96. https://doi.org/10.4102/koedoe.v46i2.57

[21] Clark, J.H. (2013) Habitat Use Analysis of a Reintroduced Black Rhino (Diceros bicornis) Population. Thesis, Honors College Capstone Experience/Thesis Project, 
Paper 402, Western Kentucky University, Bowling Green.

[22] Winkel, F. (2004) Diet Choice of the Black Rhinoceros in the Double Drift Game Reserve, South Africa. MSc Thesis, Resource Ecology Group, Wageningen University, Wageningen, 36.

[23] Tafangenyasha, C. (1997) Tree Loss in Gonarezhou National Park (Zimbabwe) between 1970and 1983. Journal of Environmental Management, 49, 355-366. https://doi.org/10.1006/jema.1996.9987

[24] Gandiwa, E., Magwati, T., Zisadza, P., Chinuwo, T. and Tafangenyasha, C. (2011) The Impact of African Elephants on Acacia tortilis Woodland in Northern Gonarezhou National Park, Zimbabwe. Journal Arid Environment, 75, 809-814. https://doi.org/10.1016/j.jaridenv.2011.04.017

[25] Mashapa, C., Nyabawa, P., Zisadza-Gandiwa, P., Muvengwi, J., Kativu, S. and Gandiwa, E. (2014) Status of African Baobab (Adansonia digitata) across Gonarezhou National Park, Zimbabwe. Journal of Applied Science \& Environmental Management, 18, 139-143. https://doi.org/10.4314/jasem.v18i1.18

[26] Kotze, D.C. and Zacharias, P.J.K. (1993) Utilisation of Woody Browse and Habitat by the Black Rhino (Diceros bicornis) in Western Itala Game Reserve. African Journal for Science, 10, 36-40. https://doi.org/10.1080/10220119.1993.9638319

[27] Emslie, H.R. and Adcock, A. (1994) Feeding Ecology of the Black Rhinoceros. In: Penzhorn, B.L. and Kreik, N.P.L., Eds., Proceedings of a Symposium on Rhinos as Game Ranch Animal, Wildlife Group of the South African Veterinary Association, Onderstepoort, 9-10 September 1994, i-iv, 1-242.

[28] Muya, S.M. and Oguge, M. (2000) Effects of Browse Availability and Quality on Black Rhino (Diceros bicornis) Diet in Nairobi National Park, Kenya. African Journal of Ecology, 38, 62-71. https://doi.org/10.1046/j.1365-2028.2000.00213.x

[29] Zisadza-Gandiwa, P., Mango, L., Gandiwa, E., Goza, D., Parakasingwa, C., Chinoitezvi, E., Shimbani, J. and Muvengwi, J. (2013) Variation in Woody Vegetation Structure and Composition in a Semi-Arid Savanna of Southern Zimbabwe. International Journal of Biodiversity and Conservation, 5, 71-77. https://doi.org/10.1155/2013/692564

[30] Mashapa, C., Zisadza-Gandiwa, P., Gandiwa, E. and Kativu, S. (2014) Abundance and Structure of Baobab (Adansonia digitata) across Various Soil Group Substrate Strata in Gonarezhou National Park, Southeast Zimbabwe. International Journal of Biodiversity, 2013, Article ID: 874713. https://doi.org/10.1155/2013/874713

[31] Gandiwa, E., Gandiwa, P. and Mxoza, T. (2012) Structure and Composition of Spirostachys africana Woodland Stands in Gonarezhou National Park, Southern Zimbabwe. International Journal of Environmental Science, 2, 234-241.

[32] Owen-Smith, R.H. (1988) Mega-Herbivores. The Influence of Very Large Body Size on Ecology. Cambridge University Press, Cambridge. https://doi.org/10.1017/CBO9780511565441

[33] Oloo, T.W., Brett, R. and Young, T.P. (1994) Seasonal Variation in the Feeding Ecology of Black Rhinos (Diceros bicornis L.) in Laikipia, Kenya. African Journal of Ecology, 32, 142-157. https://doi.org/10.1111/j.1365-2028.1994.tb00565.x

[34] Smithers, R.H.N. (1983) The Mammals of the Southern African Subregions. University of Pretoria, Pretoria. 